TITLE:

\title{
Sensory stimulation accelerates dopamine release in the basal ganglia(Abstract_要旨 )
}

$\operatorname{AUTHOR}(S)$ :

Inoue, Manabu

\section{CITATION:}

Inoue, Manabu. Sensory stimulation accelerates dopamine release in the basal ganglia. 京都大学, 2006, 博士(医学)

ISSUE DATE:

2006-01-23

URL:

http://hdl.handle.net/2433/144317

RIGHT: 


\begin{tabular}{|c|c|}
\hline 氏 & $\begin{array}{ll}\text { wo } & \text { j之 } \\
\text { 辛 } & \text { 上 }\end{array}$ \\
\hline 学位 (専攻分野) & $士$ （医 \\
\hline 学 位記番号 & 医 博 第 2926 号 \\
\hline 学位授与の日付 & 平成 18 年 1 月 23 日 \\
\hline 学位授与の要件 & 学位規則第 4 条第 1 項該当 \\
\hline 研究科・専攻 & 医学研究科脑統御医科学系専攻 \\
\hline 学位論文題目 & $\begin{array}{l}\text { Sensory stimulation accelerates dopamine release in the basal ganglia } \\
\text { (感覚刺激は大脳基底核でドパミン放出を促す) }\end{array}$ \\
\hline
\end{tabular}

論文調査委員 教授高橋良輔教授金子武嗣教 授大森治紀

論文 内容 の 要旨

背景: ヒトのドパミン投射経路は，運動に関する黒質から線条体の経路と，意欲や精神，感情に関係する腹側被蓋野から 側坐核, 辺縁系への 2 つの経路が主と考えられている。一方，ドパミンが関与するパーキンソン病やジストニアなどの疾患 では, 感覚入力によって症状の改善があることが以前から指摘されている。これは, 脳内ドパミンが, 従来考えられていた 運動，意欲とは異なった感覚刺激とも関わることを示唆するが，その関係について十分解明されていない。電気刺激による 不快感や筋肉の緊張による内因性ドパミンの変化の影響をうけにくいように，麻酔下に抢ける動物実験で感覚入力とドパミ ンの関連を検討した。

目的 ドパミン D2 受容体のトレーサーであるラクロプライドの結合能をポジトロン断層法（PET）で計測することによ って, 感覚刺激による内因性ドパミン放出の変化を明らかにする。

対象及び方法 雄成猫12匹を 2 群に分け刺激群 6 匹, 非刺激群 6 匹を対象とした。体性感覚刺激として, 一側前肢手掌に 電気刺激 $(0.5 \mathrm{~ms} 5 \mathrm{~Hz} 50 \mathrm{~mA})$ を持続的に与えた。フロセン麻酔とガラミン筋驰緩薬投与下に，炭素11標識ラクロプライ ド $9 \mathrm{mCi}$ を静脈内に投与し, 動物用 PET を用いて, 脳内への集積を60分間記録した。刺激群では, ラクロプライド投与と 同時に電気刺激を開始した。小脳の放射活性を入力関数として脳内各部位のラクロプライドの結合能を画素ごとに計算した。 MRI 上で左右の線条体と側坐核に関心領域を設定した後, 各関心領域（ROI）の結合能を左右と刺激の有無で統計検定 $(\mathrm{t}$ 検定）を行なった。また, ROI 法以外に, 近年, 人の脳活動に扔ける研究で利用されている statistical parametric mapping（SPM）を用いた検定も行なった。

結果 刺激群では非刺激群に比べて電気刺激対側の線条体, 側坐核でラクロプライドの結合能が低下していた。刺激同側 の線条体，側坐核では刺激群の有無でラクロプライドの結合能に有意差示さなかった。このことは刺激対側の線条体，側坐 核でドパミンの放出を示している。また，SPMでも同様に刺激対側の線条体，側坐核で結合能低下を示していた。

考察 末梢の電気刺激が刺激対側の脳内ドパミン放出を促進させるということは明らかとなったが, 体性感覚のうちどの 種類の感覚刺激がドパミン放出に関係しているかはまだ明らかでない。触覚や痛み刺激がドパミン放出に関係しているとの 報告より考えるとドパミンが特別な感覚で放出されるというよりも感覚刺激全般に関わっている可能性もある。今後感覚刺 激の種類を変えて実験を行なうことでドパミンの放出と感覚の種類との関係を明らかにすることが出来ると考えられる。ま た, 今回の解析結果は, SPM がネコなどの中動物でも神経伝達物質の変化を検出するのに利用できる可能性を示した。検 出機器の進歩で精度の高いデータを得ることが出来ればラットやマウスにも応用可能である。遺伝子組み替えが可能な小動 物での応用は遺伝子異常が脳内神経伝達物質に与える影響を明らかにするのに大いに役立つと考えられる。

結論 末梢の感覚刺激が内因性ドパミンの放出を促すことが示された。 


\section{論 文 審 査 の 結 果 $の$ 要 旨}

本研究の目的は, PET を用いた動物実験で脳内ドパミンと体性感覚の関係を明らかにすることにある。

実験は, 雄成猫 12 匹 2 群に分け刺激群 6 匹, 非刺激群 6 匹を対象とした。刺激群では, 炭素 11 標識ラクロプライド投与 と同時に手掌への電気刺激を開始し, 脳内への経時的な集積を動物用 PET を用いて60分間連続記録した。採血を行わず, 小脑の放射活性を入力関数とし脳内各部位の炭素11標識ラクロプライドの結合能を画素ごとに計算した。左右の線条体と側 坐核の結合能を，左右と刺激の有無で関心領域による $\mathrm{t}$ 検定と SPM で画素ごとに比較した。

結果は, 電気刺激対側の線条体・側坐核では, 刺激同側, 非刺激群の同部位と比べて炭素11標識ラクロプライドの結合能 が低下していた。SPMでも同様の結果を示した。このことは刺激対側の線条体，側坐核で内因性ドパミンが放出されてい る事実を示している。

この結果と, これまでの種々の感覚刺激が脳内ドパミン作動性神経に関係しているという報告から, 脳内ドパミンは特別 な感覚で放出されるというよりも感覚系全般に関わっている可能性がある。これは, 脳内ドパミンに関与する神経疾患に㧈 いて，感覚刺激によって症状改善があることが指摘されていることと関連する。以上の研究は，各種精神神経疾患における 脳内ドパミンの機能解明に寄与するところが多い。

従って, 本論文は博士 (医学) の学位論文として価値あるものと認める。なお, 本学位授与申請者は, 平成17年11月21日 実施の論文内容とそれに関連した試問を受け，合格と認められたものである。 